Marquette University

e-Publications@Marquette

Biomedical Engineering Faculty Research and

Publications

Biomedical Engineering, Department of

10-1-2009

\title{
Modulation of Mitochondrial Bioenergetics in the Isolated Guinea Pig Beating Heart by Potassium and Lidocaine Cardioplegia: Implications for Cardioprotection
}

Mohammed Aldakkak

Medical College of Wisconsin

David F. Stowe

Marquette University

Edward J. Lesnefsky

Virginia Commonwealth University

James S. Heisner

Medical College of Wisconsin

Qun Chen

Virginia Commonwealth University

See next page for additional authors

Accepted version. Journal of Cardiovascular Pharmacology, Vol. 54, No. 4 (October 2009): 298-309.

DOI. (C) 2009 Lippincott Williams \& Wilkins, Inc. Used with permission. 
Authors

Mohammed Aldakkak, David F. Stowe, Edward J. Lesnefsky, James S. Heisner, Qun Chen, and Amadou K.S.

Camara 


\title{
Modulation of Mitochondrial Bioenergetics in Isolated Guinea Pig Beating Heart by Potassium and Lidocaine Cardioplegia: Implications for Cardioprotection
}

\author{
Mohammed Aldakkak \\ Department of Anesthesiology, The Medical College of Wisconsin \\ Milwaukee, WI \\ David F. Stowe \\ Department of Anesthesiology, The Medical College of Wisconsin \\ Department of Physiology, The Medical College of Wisconsin \\ Cardiovascular Research Center, The Medical College of \\ Wisconsin \\ Zablocki Medical Center, Department of Veterans Affairs \\ Department of Biomedical Engineering, Marquette University \\ Milwaukee, WI \\ Edward J. Lesnefsky \\ McGuire Department of Veterans Affairs Medical Center \\ Department of Medicine, Divisions of Cardiology / Biochemistry, \\ Virginia Commonwealth University \\ Richmond, VA \\ James S. Heisner \\ Department of Anesthesiology, The Medical College of Wisconsin \\ Milwaukee, WI
}




\author{
Qun Chen \\ Department of Medicine, Divisions of Cardiology / Biochemistry, \\ Virginia Commonwealth University \\ Richmond, VA \\ Amadou K.S. Camara \\ Department of Anesthesiology, The Medical College of Wisconsin \\ Milwaukee, WI
}

\begin{abstract}
Mitochondria are damaged by cardiac ischemia-reperfusion (I/R) injury but can contribute to cardioprotection. We tested if hyperkalemic cardioplegia $(\mathrm{CP})$ and lidocaine (LID) differently modulate mitochondrial $(\mathrm{m})$ bioenergetics and protect hearts against I/R injury. Guinea pig hearts $(n=71)$ were perfused with Krebs Ringer's (KR) solution before perfusion for 1 min just before ischemia with either $\mathrm{CP}\left(16 \mathrm{mM} \mathrm{K}^{+}\right.$), or LID $(1 \mathrm{mM})$ or $\mathrm{KR}$ (control, $4 \mathrm{mM} \mathrm{K}^{+}$). The 1 min perfusion period assured treatment during ischemia but not on reperfusion. Cardiac function, $\mathrm{NADH}, \mathrm{FAD}, \mathrm{m}\left[\mathrm{Ca}^{2+}\right]$ and superoxide (ROS) were assessed at baseline, during the 1 min perfusion, and continuously during I/R. During the brief perfusion before ischemia, CP and LID decreased ROS and increased NADH without changing $\mathrm{m}\left[\mathrm{Ca}^{2+}\right]$. Additionally, CP decreased FAD. During ischemia, NADH was higher and ROS was lower after $\mathrm{CP}$ and $\mathrm{LID}$, whereas $\mathrm{m}\left[\mathrm{Ca}^{2+}\right]$ was lower only after LID. On reperfusion, NADH and FAD were more normalized, and $\mathrm{m}\left[\mathrm{Ca}^{2+}\right]$ and $\mathrm{ROS}$ remained lower after $\mathrm{CP}$ and LID. Better functional recovery and smaller infarct size after $\mathrm{CP}$ and LID were accompanied by better mitochondrial function. These results suggest that mitochondria may be implicated, directly or indirectly, in protection by CP and LID against I/R injury.
\end{abstract}

Keywords: ischemia/reperfusion, lidocaine, mitochondrial calcium load, mitochondrial redox potential, potassium cardioplegia, reactive oxygen species

\title{
Introduction
}

Myocardial injury can occur during cardiac surgery, cardiopulmonary bypass or drug-induced hypothermic circulatory arrest. Although several primary methods of preserving myocardial 
function have been developed, these techniques are being constantly modified and refined to achieve the most optimal post operative outcome. 1 Potassium depolarization is a fundamental component of modern cardioplegia ${ }^{\underline{2}}$ solutions and is an important adjunct to hypothermia in that it can provide significant added protection if ischemia occurs during cardiac surgery. However, there remains controversy over what constitutes an optimal hyperkalemic cardioplegia (CP) solution, insofar as hyperkalemia, per se, may predispose the myocardium to accumulation of intracellular $\mathrm{Na}^{+}, \underline{3}$ and may cause some deleterious effects such as cytosolic $\mathrm{Ca}^{2+}$ uptake. ${ }^{4}$ During hyperkalemic arrest the $\mathrm{Na}^{+} / \mathrm{K}^{+}$ATPase pump has been shown to be active, which may compromise recovery on reperfusion. $\frac{5}{\text { It }}$ was postulated that plasma membrane hyperpolarizing agents, such as the $\mathrm{Na}^{+}$channel blocker lidocaine (LID) might have an advantage over depolarizing, hyperkalemic solutions by providing a better maintenance of cell membrane potential and ion homeostasis. $\underline{6}$ Indeed, several studies have shown that adding a hyperpolarizing agent to a high $\mathrm{K}^{+} \mathrm{CP}$ improved function and reduced cellular damage. $\underline{-1}-\underline{10}$

Mitochondria play a key role in ischemia/reperfusion (I/R)induced injury. During I/R a decrease in cytosolic $\mathrm{pH}$ occurs because of anaerobic metabolism; this acidity leads to increased cytosolic $\mathrm{Na}^{+}$and in tandem to increased cytosolic $\mathrm{Ca}^{2+}$. As a result, mitochondrial $\mathrm{Ca}^{2+}$ $\left(\mathrm{mCa}^{2+}\right)$ can rise to a high level, which can lead to abrupt cell death or eventually to opening of the mitochondrial permeability transition pore (MPTP), which allows released cytochrome $c$ and other factors to trigger apoptotic cell death. Mitochondria also play a key role in generating reactive $\mathrm{O}_{2}$ species (ROS), not only during reperfusion, but also during ischemia; ROS contribute to mitochondrial injury and subsequent cell damage. $\underline{11} \underline{13}$ Therefore, targeting the mitochondrion to alleviate I/R injury has engendered much interest in understanding the mitochondrial component of cardioprotection. Indeed, we $\underline{14}-\underline{16}$ and other investigators ${ }^{17}$ have shown recently that targeting mitochondrial electron transport chain (ETC) complex I protected against I/R injury.

CP and LID, in addition to their mechanism of action to arrest action potential and contractile activity, may also have direct or indirect effects at the mitochondrial level. We questioned if CP or LID would better preserve mitochondrial bioenergetics and protect against myocardial I/R injury by a brief reduction in metabolic activity before 
ischemia (indirect effect), or by an effect on mitochondrial bioenergetics during ischemia (direct effect). To address this we investigated effects of both CP and LID on the mitochondrial redox state, ROS, and mitochondrial $\mathrm{Ca}^{2+}\left(\mathrm{m}\left[\mathrm{Ca}^{2+}\right]\right)$ as each variable was measured continuously in intact beating hearts during I/R. We hypothesized that CP or LID, given just before ischemia, would differentially preserve mitochondrial redox state and decrease ROS generation and $\mathrm{m}\left[\mathrm{Ca}^{2+}\right]$ during I/R. To our knowledge, this is the first study to compare the effects of these two methods of arresting hearts on mitochondrial function measured continuously in isolated perfused hearts.

\section{Materials and Methods}

\section{Langendorff Heart Preparation}

The investigation conformed to the Guide for the Care and Use of Laboratory Animals (US National Institutes of Health Publication No. 85-23, Revised 1996). The Medical College of Wisconsin Biomedical Resources Studies Committee approved this study. Guinea pig hearts $(n=71)$ were isolated and prepared as previously described in detail. $\underline{18}$ $\underline{23}$ Animals were anesthetized with ketamine $(50 \mathrm{mg} / \mathrm{kg}$ ) and heparin was administered to prevent clotting. Following decapitation and thoracotomy, hearts were removed and perfused at $55 \mathrm{mmHg}$ via the aortic root with a Krebs Ringer's solution (KR: in $\mathrm{mM} 138 \mathrm{Na}^{+}, 4.5 \mathrm{~K}^{+}$, $1.2 \mathrm{Mg}^{2+}, 2.5 \mathrm{Ca}^{2+}, 134 \mathrm{Cl}^{-}, 15 \mathrm{HCO}^{3-}, 1.2 \mathrm{H}^{2} \mathrm{PO}^{4-}, 11.5$ glucose, 2 pyruvate, 16 mannitol, 0.1 probenecid, 0.05 EDTA, and $5 \mathrm{U} / \mathrm{L}$ insulin) gassed with $3 \% \mathrm{CO}_{2}, 97 \% \mathrm{O}_{2}(\mathrm{pH} 7.4)$ at $37^{\circ} \mathrm{C}$. Pyruvate improves performance in guinea pig hearts, $\underline{24}, \underline{25}$ and mannitol, a non-metabolized sugar, supports the oncotic pressure of the KR solution. Probenecid was added to accentuate loading of fluorescent dyes. $\underline{26}$ A saline-filled balloon catheter attached to a transducer was used to measure LV pressure (LVP). Coronary flow was measured using an ultrasonic flowmeter (model T106X; Transonic Systems, Ithaca, NY) placed directly into the aortic inflow line as previously described. $\underline{18-\underline{23}}$ Spontaneous heart rate was monitored with bipolar electrodes placed in the right atrial and ventricular walls. $\underline{27}$ Cardiac $\mathrm{O}_{2}$ delivery was calculated as coronary flow $\bullet$ heart weight ${ }^{-1} \bullet \mathrm{Pa}_{\mathrm{o} 2} \bullet 24 \mu \mathrm{O}_{2} / \mathrm{ml}$ $\left(37^{\circ} \mathrm{C}\right)$ at $760 \mathrm{mmHg}, \mathrm{O}_{2}$ consumption $\left(\mathrm{MVO}_{2}\right)$ as coronary flow • heart 
NOT THE PUBLISHED VERSION; this is the author's final, peer-reviewed manuscript. The published version may be accessed by following the link in the citation at the bottom of the page.

weight ${ }^{-1} \cdot\left(\mathrm{Pa}_{\mathrm{O} 2}-\mathrm{Pv}_{\mathrm{O} 2}\right) \cdot 24 \mu \mathrm{O}_{2} / \mathrm{ml}\left(37^{\circ} \mathrm{C}\right)$ at $760 \mathrm{mmHg}$, and cardiac efficiency as developed LVP • heart rate / $\mathrm{MVO}_{2}$.

\section{Measurements of Cardiac Mitochondrial Redox State, $\mathrm{O}_{2}{ }^{--}$and $\left[\mathrm{Ca}^{2+}\right]$}

All fluorescence signals were detected at $10^{3}$ to $10^{5}$ photons/s. FAD fluorescence is derived only from mitochondria; the majority of the NADH signal also arises from mitochondria $\underline{28}$ - $\underline{30}$ The majority of superoxide $\left(\mathrm{O}_{2}{ }^{--}\right)$likely originates from cardiac mitochondria with only small part derived from non-mitochondrial sources because $\mathrm{O}_{2}{ }^{\bullet-}$ generation in the isolated heart is very sensitive to mitochondrial inhibitors and insensitive to inhibitors of xanthine oxidase. $\underline{19}$ It is also possible that non-myocyte sources such as endothelial and other sources can contribute to the total $\mathrm{O}_{2}{ }^{--}$generated. For example, the mitochondrial content in endothelial cells ranges between $2-5 \%$ while mitochondria comprise $22-37 \%$ of the volume of cardiac myocytes. 32,33 These observations lead to the conclusion that most of the $\mathrm{O}_{2}{ }^{-}$ generated in ischemic hearts originates in mitochondria of cardiac myocytes. Myocardial $\mathrm{Ca}^{2+}$ signals arise from noncytosolic sources after quenching by $\mathrm{MnCl}_{2} ;$;4 the major noncytosolic source is the mitochondrial compartment because of its large volume relative to cell volume. $\underline{32,33}$

$\mathrm{NADH}$ and $\mathrm{FAD}, \mathrm{m}\left[\mathrm{Ca}^{2+}\right]$, and ROS production were measured near continuously through the LV free wall using one of four excitation and emission fluorescence spectra $\frac{18-23}{2}$ in different subsets of hearts. A trifurcated fiberoptic probe $\left(3.8 \mathrm{~mm}^{2} /\right.$ bundle) was placed against the LV to excite and record light signals at specific wavelengths using spectrophotofluorometers (SLM Instruments Inc, Urbana, IL; or Photon Technology International, London, Ontario). Light penetration and its fluorescence sensitivity are dependent on the light source intensity and wavelength. For $\mathrm{Ca}^{2+}$ the signal is transmural but attenuated at the endocardial surface to 20 to $30 \%$ of that at the epicardial surface. $\underline{35}$

In a subset of hearts, as described previously, $\underline{20,21}, \underline{36} 10 \mu \mathrm{M}$ dihydroethidium (DHE), a fluorescent probe used to detect the $\mathrm{O}_{2}{ }^{--}$ radical, $\underline{37-39}$ was loaded for 20 min and washed out, the LV free wall was excited at $540 \mathrm{~nm}$, and light emission was recorded at $590 \mathrm{~nm}$. 
$\mathrm{O}_{2}{ }^{\bullet-}$ non-enzymatically converts DHE to 2-hydroxyethidium (2-OH-E ${ }^{+}$) or a precursor that appears to be rapidly made, is labile, and fluoresces at a slightly shorter wavelength than the heme-peroxidase oxidation product ethidium that can intercalate to bind with DNA. $\underline{38}, \underline{39}$ In other hearts NADH autofluorescence was assessed at $350 \mathrm{~nm}$ excitation and 450 and $390 \mathrm{~nm}$ emissions, and FAD autofluorescence at $480 \mathrm{~nm}$ excitation and $540 \mathrm{~nm}$ emission. $\underline{14}, \underline{22}, \underline{30}, \underline{40}$

Alternatively, other hearts were loaded with $6 \mu \mathrm{M}$ indo $1 \mathrm{AM}$ for $30 \mathrm{~min}$ to measure $\mathrm{Ca}^{2+}$ transients using an excitation of $350 \mathrm{~nm}$ and emissions of 390 and $450 \mathrm{~nm}$. After initially observing cytosolic $\mathrm{Ca}^{2+}$ transients, hearts were perfused for 15 min with $100 \mu \mathrm{M} \mathrm{MnCl}_{2}$ to quench the cytosolic indo 1 signal $\underline{41}, \underline{42}$ and then washed out for $15 \mathrm{~min}$. $\mathrm{MnCl}_{2}$ slightly increased LVP which returned to its original value upon washout. The remaining fluorescent signal after quenching represented the $\mathrm{m}\left[\mathrm{Ca}^{2+}\right]$ signal. $\underline{34}$ To estimate actual $\mathrm{m}\left[\mathrm{Ca}^{2+}\right]$ during the entire protocol, NADH autofluorescence was subtracted from the underlying changes in $\mathrm{mCa}^{2+}$ fluorescent signals for each group. $\underline{14}, \underline{27}, \underline{43}$ Each signal was digitized and recorded at $200 \mathrm{~Hz}$ on computers for later analysis using specifically designed computational programs and commercial software. $\mathrm{pH}$ alone in the range of 6.2-8.0 does not alter the DHE fluorescence in our model. $\underline{\underline{20}}$ Also in preliminary experiments, we found that a decrease in $\mathrm{pH}$ from 7.4 to 6.5 did not significantly change the indo $1 \mathrm{AM}$ fluorescence signal, and that the effects of low $\mathrm{pH}$ on NADH are negligible. This excludes the possibility of lactic acidosis buildup during ischemia from having significant effects on $\mathrm{mCa}^{2+}, \mathrm{O}_{2}{ }^{\bullet-}$, and NADH signals during ischemia.

\section{Protocol}

The study had four groups: control $\left(\mathrm{CON},\left[\mathrm{K}^{+}\right]\right.$at $\left.4 \mathrm{mM}, \mathrm{n}=15\right)$; high $\left[\mathrm{K}^{+}\right]$cardioplegia in $\mathrm{KR}$ solution $\left(\mathrm{CP},\left[\mathrm{K}^{+}\right]\right.$at $\left.16 \mathrm{mM}, \mathrm{n}=21\right)$; lidocaine in KR solution ( $L I D, 1 \mathrm{mM}, \mathrm{n}=20)$; and time control $(n=15)$. Each group contained subsets of hearts to independently measure and record either $\mathrm{NADH}$ plus $\mathrm{FAD}, \mathrm{m}\left[\mathrm{Ca}^{2+}\right]$, or $\mathrm{O}_{2}{ }^{\bullet-}$. Each heart initially underwent a stabilization period followed by loading and washout of unbound dye to specifically measure either $\mathrm{m}\left[\mathrm{Ca}^{2+}\right]$ or $\mathrm{O}_{2}{ }^{\circ-}$. $\mathrm{NADH}$ and FAD autofluorescence were assessed simultaneously $\underline{14}, \underline{27}, \underline{43}, \underline{44}$ using a protocol similar to that of the indo 1 fluorescence dye-loaded hearts. 
All hearts undergoing ischemia were perfused for only 1 min with either KR alone (CON), CP, or LID immediately before the onset of 30 min no flow global ischemia. This protocol assured that hearts were treated only during the ischemic period and not during reperfusion. This treatment effect is not a classical preconditioning protocol in which a drug is first washed out before ischemia. In our protocol hearts began to beat immediately on reperfusion in the CP and LID treated hearts. This confirms that effects of CP and LID were limited to the 1 min perfusion and during ischemia.

$\mathrm{CP}$ and LID did not alter the fluorescence characteristics or spectra of any dye. Therefore, any observed changes in fluorescent spectra were most likely attributed only to the effects induced by I/R. After ischemia each heart was reperfused with KR solution for 120 min without additional treatment. At the end of each experiment hearts were removed and atria were discarded; ventricles were cut into thin transverse sections (4-5) of approximately $3 \mathrm{~mm}$ each and incubated in buffered $0.1 \% 2,3,5$-triphenyltetrazolium chloride (TTC) to stain viable tissue from necrotic tissue for estimating infarct size.

\section{Statistical Analysis}

Measurements for each group were compared at baseline, during the $1 \mathrm{~min}$ treatment before ischemia, at 15 and $30 \mathrm{~min}$ ischemia, and at 5, 30, 60, and 120 min reperfusion. All data are expressed as mean \pm SEM. Values for $\mathrm{NADH}, \mathrm{FAD}$ and $\mathrm{O}_{2}{ }^{\circ-}$ are expressed in arbitrary fluorescence units (afu) with the times factors for photon units/s removed, and $\mathrm{m}\left[\mathrm{Ca}^{2+}\right]$ is given in $\mathrm{nM}$. Between groups and within group comparisons were done by two-way analysis of variance to determine significance. If $\mathrm{F}$ values were significant $(P<$ 0.05), post hoc comparisons of means tests (Student-Newman-Keuls) were used to compare the three groups within each subset. Differences between means were considered significant when $P<0.05$ (two-tailed).

\section{Results}

Baseline values were not different among groups for all measurements. To assess the role of mitochondria in the overall 
cardiac functional and metabolic recovery afforded by $\mathrm{CP}$ and LID, mitochondrial function, i.e., $\mathrm{NADH}$ plus $\mathrm{FAD}, \mathrm{O}_{2}{ }^{--}$production, and $\mathrm{m}\left[\mathrm{Ca}^{2+}\right]$ were monitored in different subsets of hearts undergoing the same protocol described earlier. Figures 1(a) and 2(a) show respectively timeline changes in $\mathrm{NADH}$ (baseline value $55 \pm 0.2 \mathrm{afu}$ ) and FAD (baseline value $61 \pm 0.7 \mathrm{afu}$ ) (indicators of mitochondrial redox state) before, during, and after ischemia. An increase in NADH and a decrease in FAD indicate a more reduced mitochondrial state, while a decrease in NADH and an increase in FAD indicate a more oxidized state. $14, \underline{43}$ Ischemia initially caused an increase in NADH

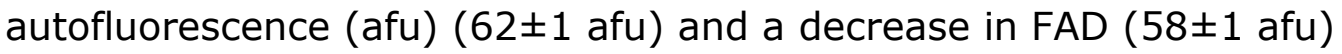
autofluorescence in each group indicating a more reduced redox state during the onset of ischemia. During late ischemia mitochondria became less reduced as shown by the decline in NADH ( $56 \pm 3 \mathrm{afu}$ ) in the CON group. The CP and LID groups did not show a decline in NADH as did the CON group during ischemia (64 $2,65 \pm 3$ afu, respectively). By 60 min reperfusion mitochondrial redox state (NADH and FAD) returned to baseline in $\mathrm{CP}$ and LID treated hearts (NADH: $52 \pm 1,53 \pm 1$, FAD: $61 \pm 1,63 \pm 1$ afu, respectively) but was markedly compromised in

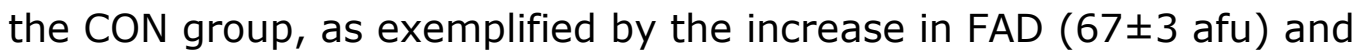
decrease in NADH (46 1 afu) above and below baseline, respectively. This indicates that mitochondrial redox potential was better preserved with CP and LID treatment, while mitochondria exhibited a more oxidized state in the CON group. 
NOT THE PUBLISHED VERSION; this is the author's final, peer-reviewed manuscript. The published version may be accessed by following the link in the citation at the bottom of the page.

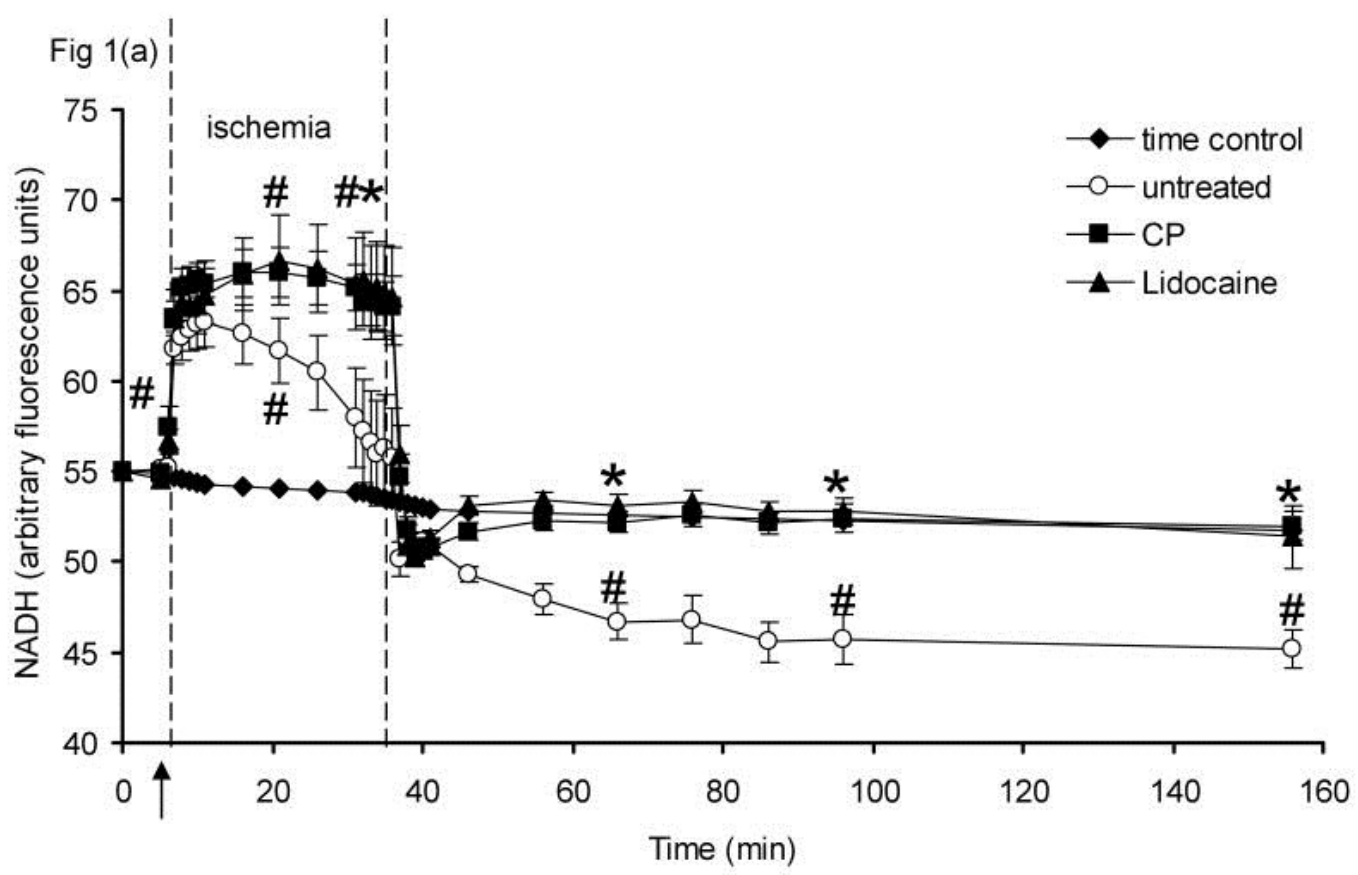

Fig 1 (b)

$\square$ baseline

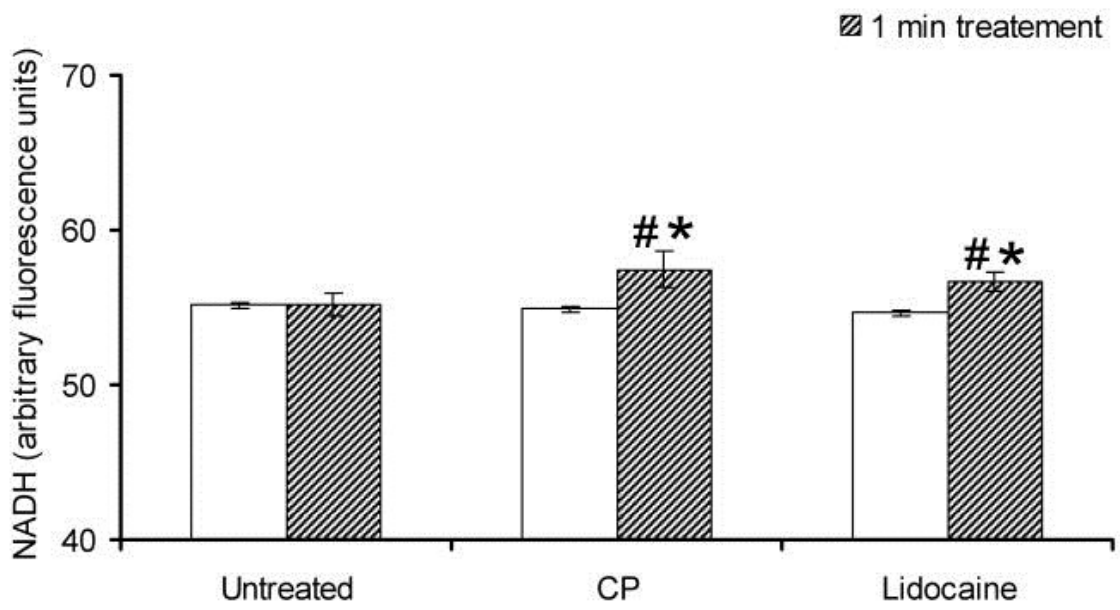

Figure 1. (a). Change in NADH autofluorescence before, during, and after $30 \mathrm{~min}$ no flow, global ischemia for CON $(n=5), \operatorname{CP}(n=8)$, and LID $(n=5)$ groups. Time control experiments $(n=5)$ without concomitant ischemia are also shown. Arrow indicates 1 min CP or LID perfusion immediately before ischemia. Figure 1(b). Effect of CP or LID perfusion before ischemia on $\mathrm{NADH}$; white and hatched bars represent baseline and 1 min of treatment. \#P<0.05, 1 min perfusion before ischemia, during ischemia and reperfusion vs. baseline values; $* P<0.05 \mathrm{CP}$ or LID vs. CON; $+P<0.05$ LID vs. CP (non significant, ns). 
NOT THE PUBLISHED VERSION; this is the author's final, peer-reviewed manuscript. The published version may be accessed by following the link in the citation at the bottom of the page.

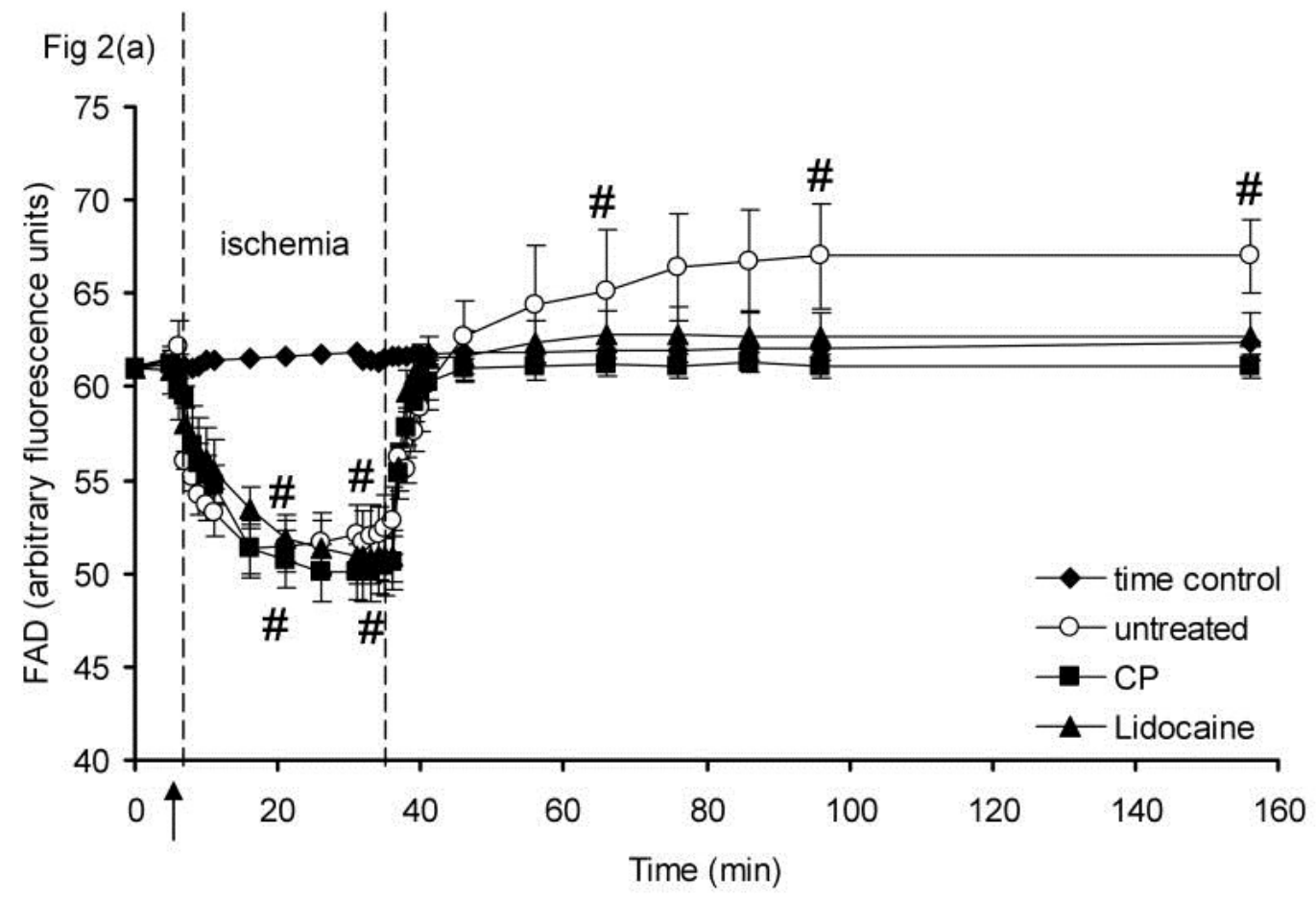

Fig 2(b)

$\square$ baseline

1 min treatment

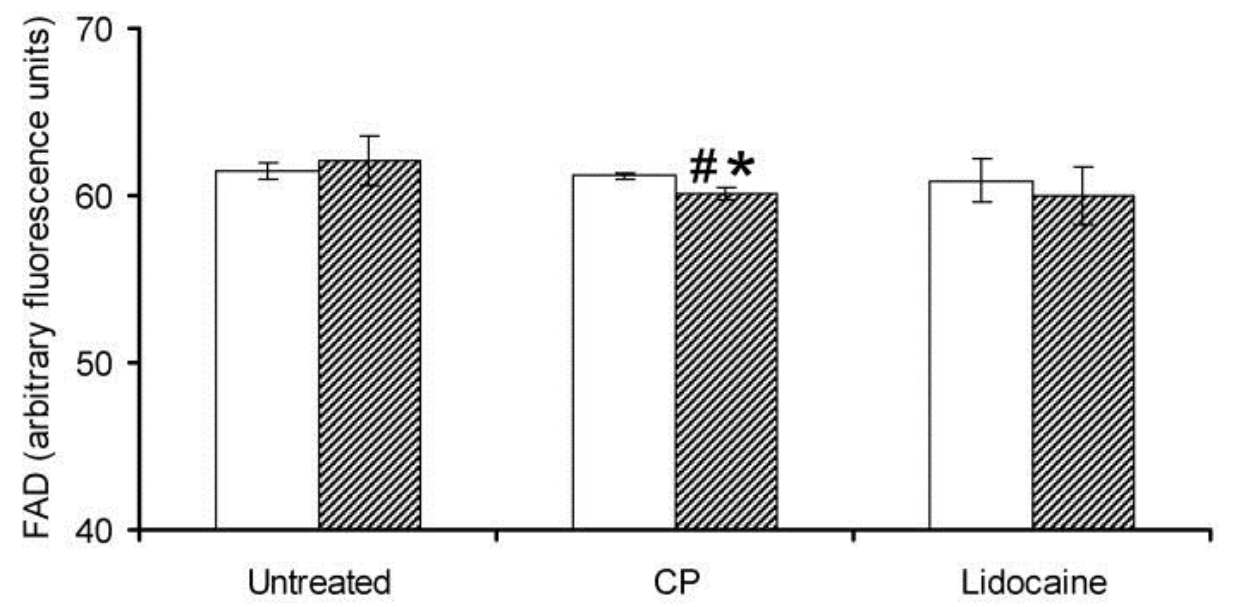

Figure 2. (a). Changes in FAD autofluorescence before, during, and after 30 min no flow, global ischemia for CON $(n=5), C P(n=8)$, and LID $(n=5)$ groups. Time control experiments $(n=5)$ without concomitant ischemia are also shown. Arrow indicates 1 min CP or LID perfusion immediately before ischemia. Figure 2(b). Effect of CP or LID perfusion before ischemia on FAD; white and hatched bars represent baseline and 1 min of treatment. $\# P<0.05,1$ min perfusion before ischemia, during ischemia and reperfusion vs. baseline values; $* P<0.05$ CP or LID vs. CON; $+P<0.05$ LID vs. CP (ns). 
To evaluate the direct or indirect impact on mitochondrial redox state by CP and LID, NADH and FAD were monitored during the 1 min perfusion of each treatment before ischemia as shown in Figures 1(b) and 2 (b). The baseline values were not significantly different among groups (average basal NADH: $55 \pm 0.2$ afu) and FAD (average basal FAD: $61 \pm 0.7 \mathrm{afu})$. One min of CP or LID perfusion just before ischemia increased $\mathrm{NADH}$ (57.5 \pm 1.1 and $56.7 \pm 0.6$ afu respectively); 1 min $\mathrm{CP}$ perfusion before ischemia slightly decreased FAD (60.1 $\pm 0.4 \mathrm{afu})$; LID caused no change in FAD.

Whereas NADH and FAD are markers of the mitochondrial redox state during $\mathrm{I} / \mathrm{R}$ injury, $\mathrm{O}_{2}{ }^{--}$production and $\mathrm{m}\left[\mathrm{Ca}^{2+}\right]$ are key effectors in the mechanism of cellular injury following I/R. Figure 3(a) shows that the $\mathrm{O}_{2}{ }^{-*}$ (average baseline value $3.31 \pm 0.02$ afu) level increased in all groups at the onset of ischemia but surged significantly higher during late ischemia in the CON group ( $4.38 \pm 0.16 \mathrm{afu})$, but not in the CP (3.95 $\pm 0.11 \mathrm{afu})$ and LID (3.65 $\pm 0.13 \mathrm{afu})$ groups. During the first 20 min of reperfusion $\mathrm{O}_{2}{ }^{--}$production returned to baseline in $\mathrm{CP}$ (3.2 $\pm 0.06 \mathrm{afu}$ ) and LID (3.23 $\pm 0.06 \mathrm{afu})$ groups, but remained significantly elevated in the CON group (3.57 $\pm 0.14 \mathrm{afu}) . \mathrm{m}\left[\mathrm{Ca}^{2+}\right]$ (average baseline value $153 \pm 3 \mathrm{nM}$ ) tended to increase less so during early and late ischemia in the LID group ( $344 \pm 82 \mathrm{nM}$ at $30 \mathrm{~min}$ ischemia) than in the CON (569 $\pm 58 \mathrm{nM}$ at $30 \mathrm{~min}$ ischemia) and $\mathrm{CP}$ $(573 \pm 119 \mathrm{nM}$ at $30 \mathrm{~min}$ ischemia) groups (Figure 4(a)). On reperfusion, the high $\mathrm{m}\left[\mathrm{Ca}^{2+}\right]$ that occurred during ischemia was rapidly reversed toward baseline levels in both CP $(213 \pm 9 \mathrm{nM}$ at $5 \mathrm{~min}$ reperfusion) and LID (173 $\pm 7 \mathrm{nM}$ at 5 min reperfusion) groups, whereas it remained significantly elevated above baseline in the CON group throughout reperfusion ( $374 \pm 41 \mathrm{nM}$ at 5 min reperfusion). 
NOT THE PUBLISHED VERSION; this is the author's final, peer-reviewed manuscript. The published version may be accessed by following the link in the citation at the bottom of the page.
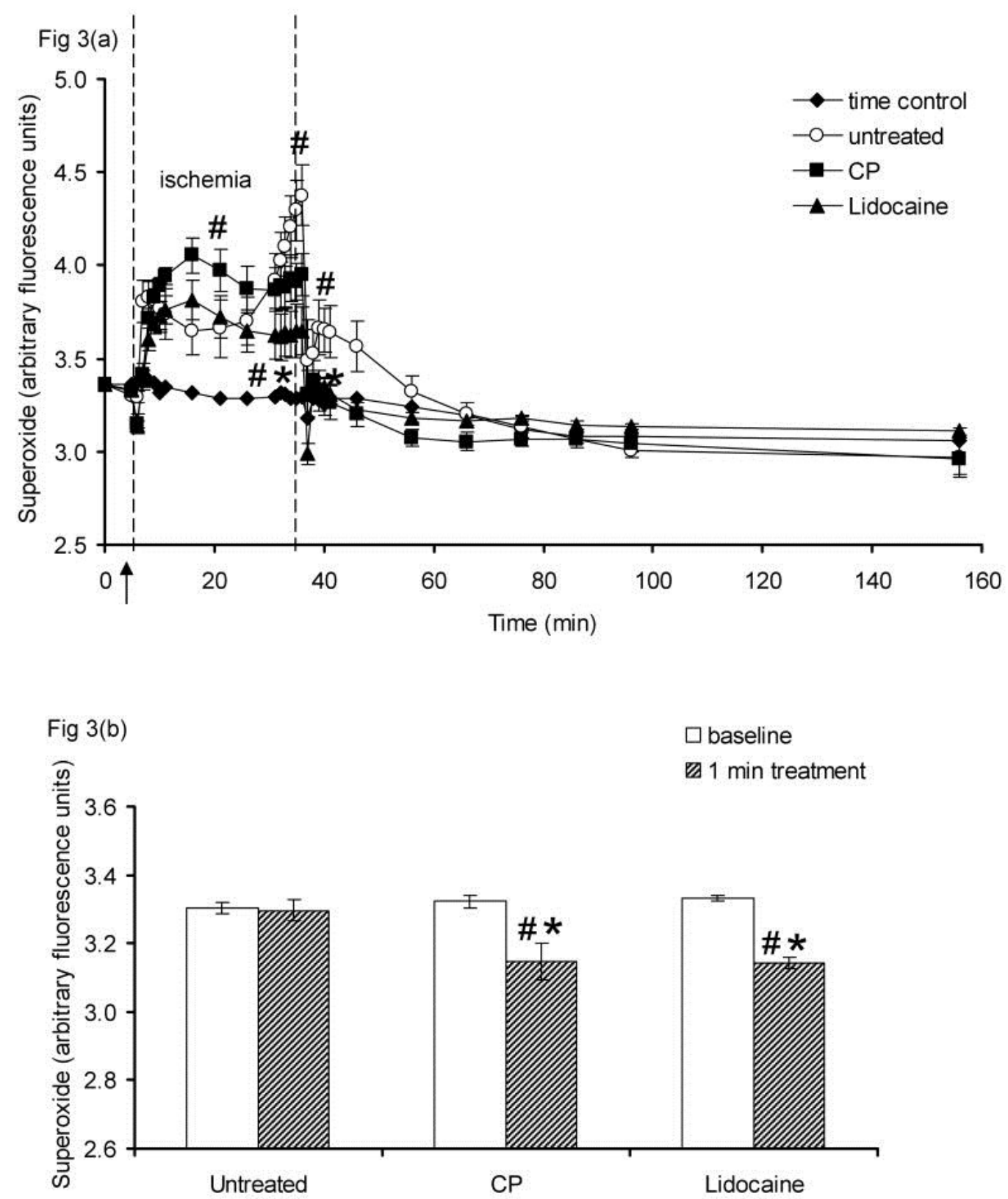

Figure 3. (a). Changes in superoxide $\left(\mathrm{O}_{2}{ }^{*-}\right)$ levels before, during, and after $30 \mathrm{~min}$ no flow, global ischemia for CON $(n=5), \operatorname{CP}(n=6)$, and LID $(n=6)$ groups. Time control experiments $(n=5)$ without concomitant ischemia are also shown. Arrow indicates 1 min CP or LID perfusion immediately before ischemia. Figure 3(b). Effect of CP or LID perfusion before ischemia on $\mathrm{O}_{2}{ }^{\cdots}$; white and hatched bars represent baseline and 1 min of treatment. \#P<0.05, 1 min perfusion before ischemia, during ischemia and reperfusion vs. baseline values; $* P<0.05 \mathrm{CP}$ or LID vs. CON; $+P<0.05$ LID vs. CP (ns). 
NOT THE PUBLISHED VERSION; this is the author's final, peer-reviewed manuscript. The published version may be accessed by following the link in the citation at the bottom of the page.

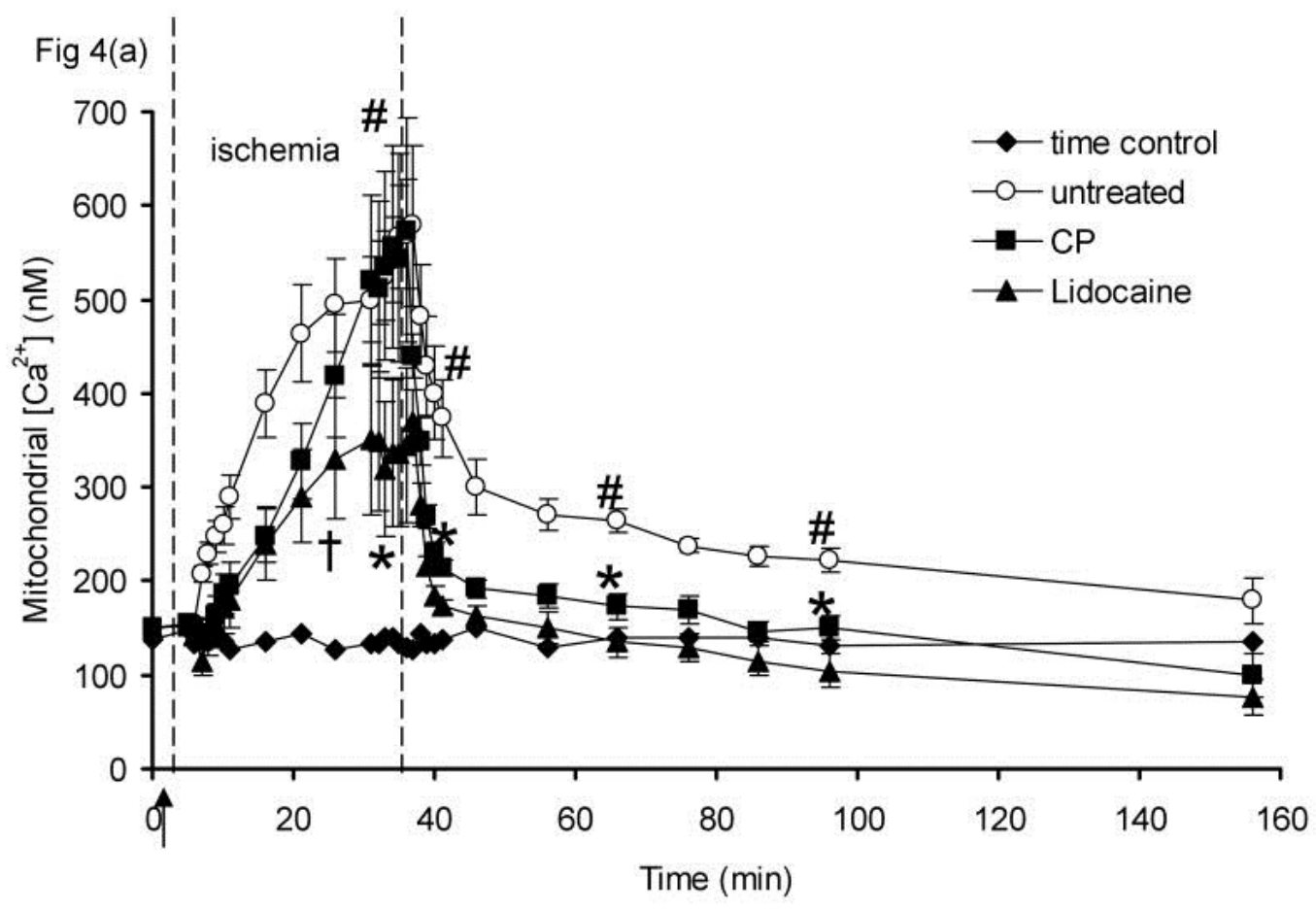

Fig 4(b)

$\square$ baseline

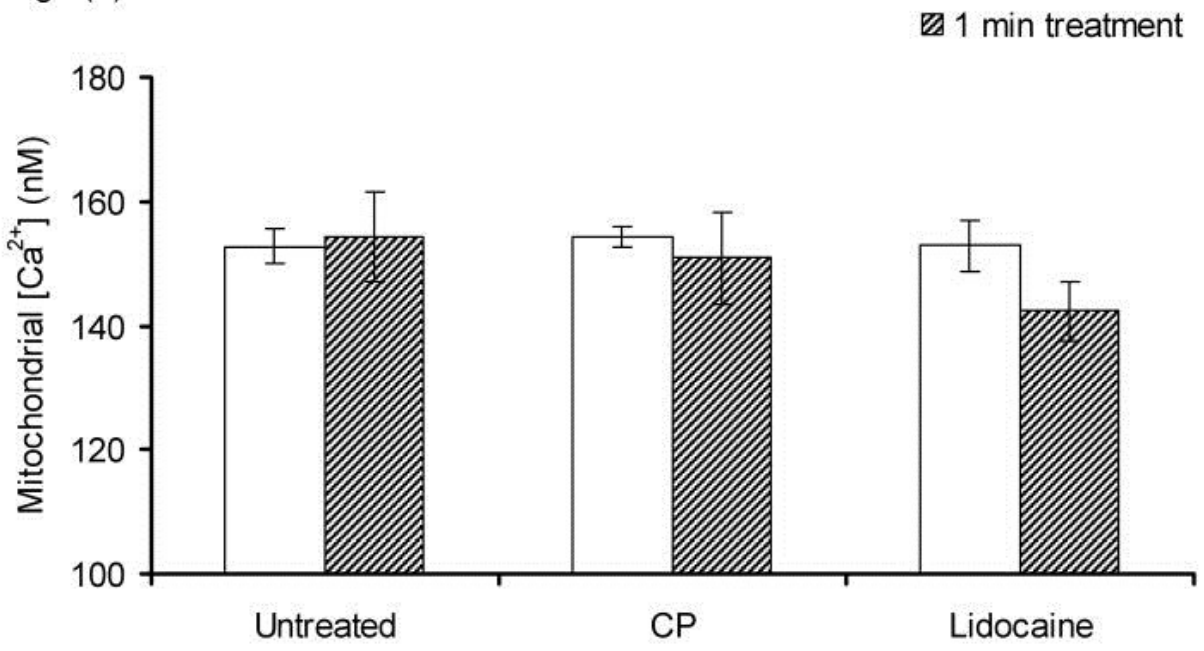

Figure 4. (a). Changes in $\mathrm{m}\left[\mathrm{Ca}^{2+}\right]$ before, during, and after 30 min no flow, global ischemia for CON $(n=5), C P(n=6)$, and LID $(n=7)$ groups. Time control experiments $(n=5)$ without concomitant ischemia are also shown. Arrow indicates $1 \mathrm{~min}$ CP or LID perfusion immediately before ischemia. Figure 4(b). Effect of CP or LID perfusion before ischemia on $\mathrm{m}\left[\mathrm{Ca}^{2+}\right]$; white and hatched bars represent baseline and $1 \mathrm{~min}$ of treatment. $\# P<0.05,1$ min perfusion before ischemia, during ischemia and reperfusion vs. baseline values; $* P<0.05 \mathrm{CP}$ or LID vs. CON; $+P<0.05$ LID vs. CP. 
Figures $3(b)$ and $4(b)$ summarize changes in $\mathrm{O}_{2}{ }^{*-}$ production and $\mathrm{m}\left[\mathrm{Ca}^{2+}\right]$, respectively, during the one min treatment with either $\mathrm{CP}$ or LID. $\mathrm{O}_{2}{ }^{--}$production decreased slightly with CP or LID treatment, whereas $\mathrm{m}\left[\mathrm{Ca}^{2+}\right]$ did not change.

Ventricular infarct size as a percentage of total ventricular weight (area at risk) for all subgroups after 120 min reperfusion was significantly larger in the CON $(40 \pm 2 \%)$ group than in the CP $(28 \pm 3 \%)$ and LID $(23 \pm 3 \%)$ groups. Infarcted tissue was confined principally to the LV mesomyocardium.

All hearts beat spontaneously and there were no significant differences in heart rate among groups at baseline. Figures 6(a) and 6(b) show timeline changes in systolic minus diastolic LVP (developed LVP) and diastolic LVP (diaLVP), respectively. Both treatments arrested all hearts during the 1 min period of perfusion with the arrest by LID as prompt as for $\mathrm{CP}$, and on reperfusion $\mathrm{CP}$ and LID treated hearts began to beat immediately. At 5 min reperfusion developed LVP was higher and diaLVP was lower in CP and LID groups than in the CON group. By the end of reperfusion developed LVP and diaLVP in CP and LID groups were similar to baseline values, whereas they remained significantly depressed and elevated below and above baseline, respectively, in the CON group. CP and LID caused a small, nonsignificant decrease in coronary flow (Figure 7(a)) during the 1 min perfusion before ischemia; during early reperfusion there was a reactive flow increase that was larger in the CP and LID groups than in the CON group. Throughout the 120 min reperfusion period coronary flow remained higher in the two treatment groups than in the CON group. Effects of both treatments and control on cardiac efficiency at baseline and during reperfusion are summarized (Figure 7(b)). Cardiac efficiency was higher after either CP or LID throughout reperfusion. 

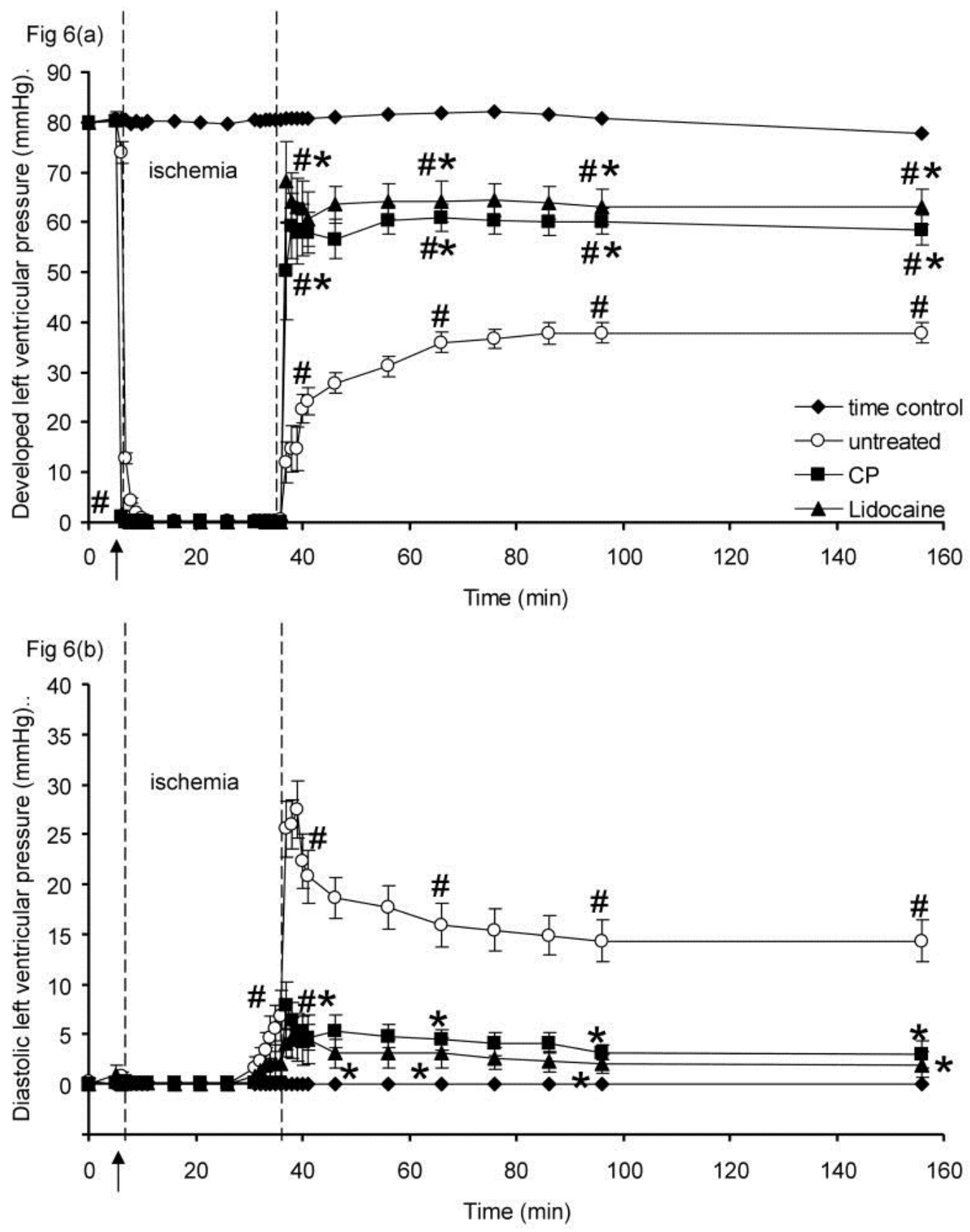

Figure 6. Left ventricular developed pressure (systolic-diastolic LVP (a)), and diastolic left ventricular pressure (diaLVP (b)) before, during, and after 30 min no flow, global ischemia for CON $(n=10), C P(n=15)$, and LID $(n=14)$ groups. Time control experiments $(n=10)$ without concomitant ischemia are also shown. Arrow indicates 1 min CP or LID perfusion immediately before ischemia. \#P<0.05, 1 min perfusion before ischemia, during ischemia and reperfusion vs. baseline values; $* P<0.05 \mathrm{CP}$ or LID vs. CON; $+P<0.05$ LID vs. CP (ns). 


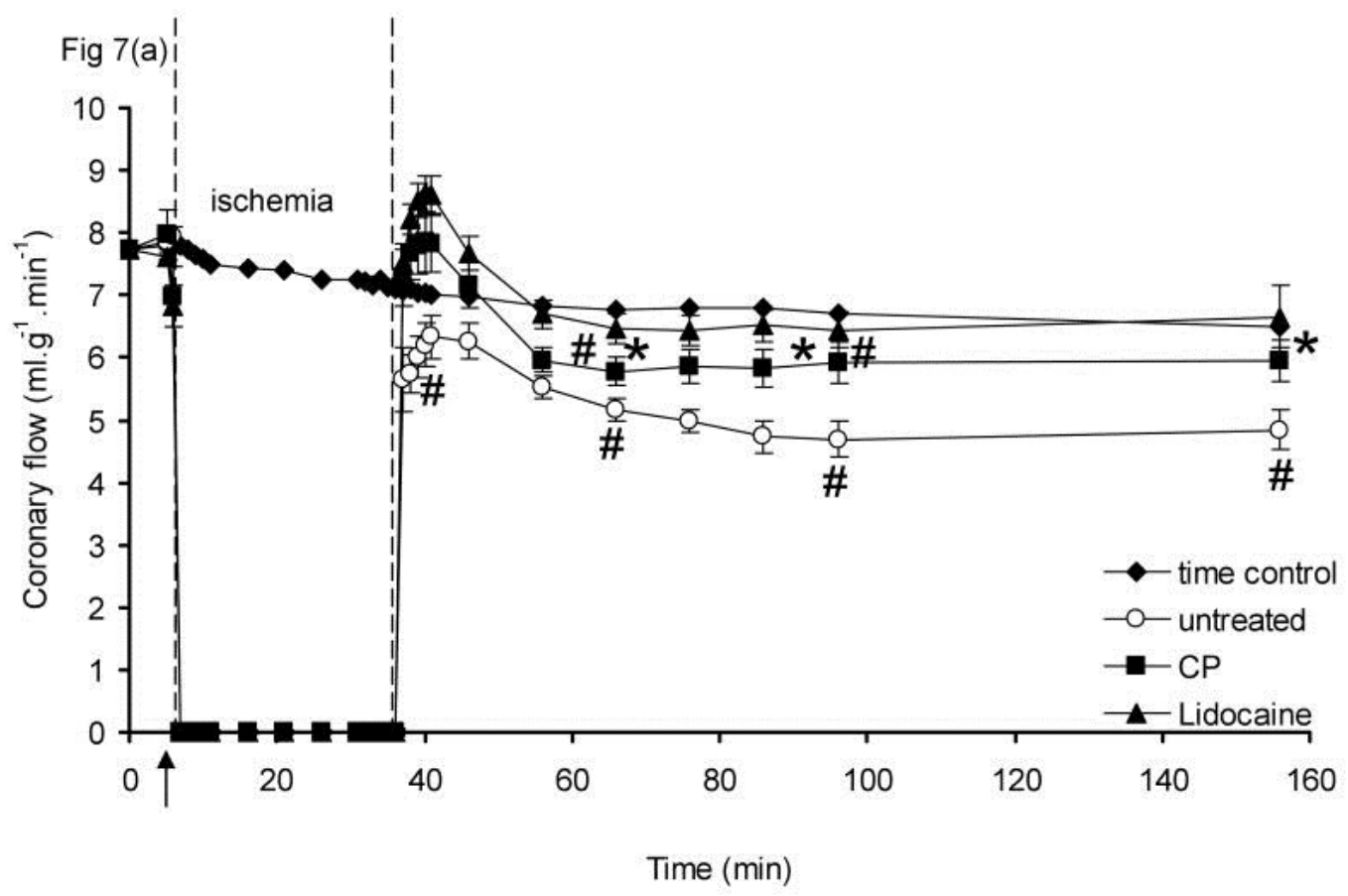

Fig 7(b)

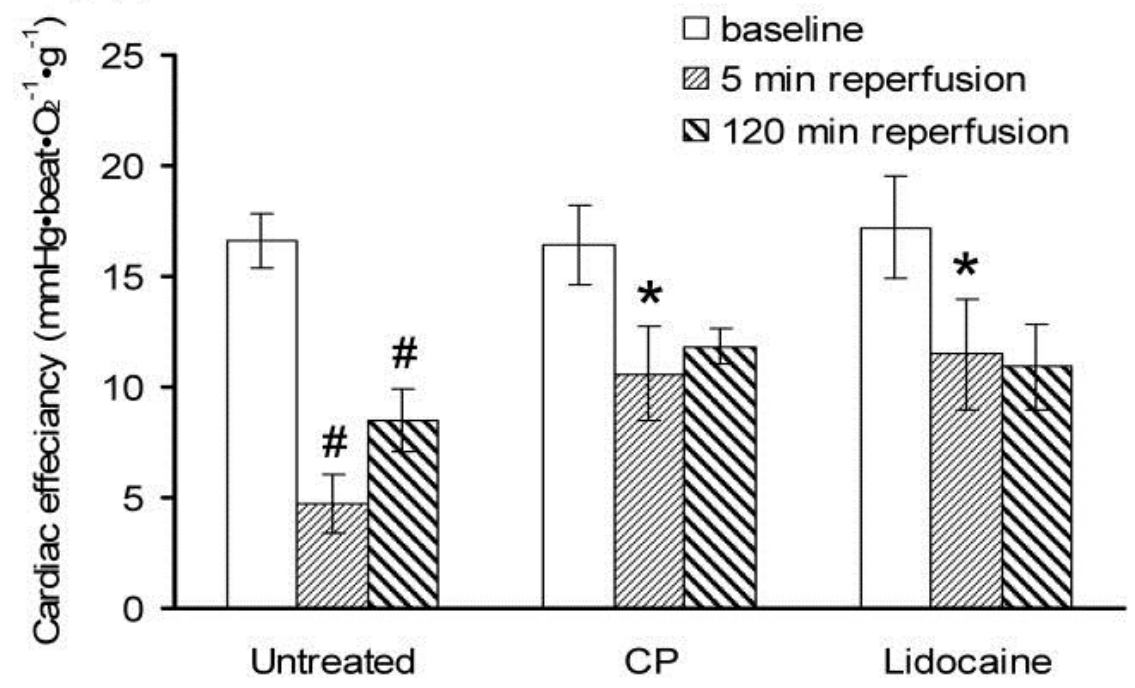

Figure 7. (a). Coronary flow before, during, and after 30 min no flow, global ischemia for CON $(n=10), C P(n=15)$, and LID $(n=14)$ groups. Time control experiments $(n=10)$ without concomitant ischemia are also shown. Arrow indicates 1 min CP or LID perfusion immediately before ischemia. Figure 7(b). Effects of CP and LID on cardiac efficiency at selected time points during reperfusion. $\# P<0.05,1 \mathrm{~min}$ perfusion before ischemia, during ischemia and reperfusion vs. baseline values; $* P<$ 0.05 CP or LID vs. CON; $+P<0.05$ LID vs. CP (ns).

Cardiac contraction, cardiac relaxation, and metabolic data for all groups at selected times of reperfusion after ischemia were 
compared to their respective baseline values (Table 1). Baseline values were similar in all groups. On reperfusion, each index was more improved in the two treatment groups than in the CON group, which was consistent with the functional data. Note that the timeline for mitochondrial variables and cardiac functions in the time control group remained unchanged during the duration of the protocol indicating stability of the preparation. Thus changes observed in the I/R groups are solely attributed to pathophysiological conditions.

\section{Baseline Reperfusion Reperfusion Reperfusion Reperfusion $5 \mathrm{~min} \quad 30 \mathrm{~min} \quad 60 \mathrm{~min} \quad 120 \mathrm{~min}$}

$\mathrm{O}_{2}$ Delivery

$\begin{array}{llllll}\text { Control } & 139.2 \pm 12.3 & 110.9 \pm 13.5^{\#} & 90.8 \pm 9.2^{\#} & 86.7 \pm 8.2^{\#} & 94.5 \pm 8.8^{\#} \\ \text { CP } & 160.9 \pm 11.2 & 186.1 \pm 11.6^{\# *} & 131.2 \pm 10.1^{\# *} & 129.8 \pm 9.4^{\# *} & 136.8 \pm 8.8^{\# *} \\ \text { LID } & 139.5 \pm 7.0 & 164.3 \pm 6.6^{\# *} & 121.7 \pm 8.0^{*} & 113.7 \pm 6.4^{\# *} & 128.8 \pm 5.3^{*}\end{array}$

$\mathrm{O}_{2}$ Consumption

$\begin{array}{llllll}\text { Control } & 86.8 \pm 5.4 & 65.7 \pm 5.5^{\#} & 58.4 \pm 5.3^{\#} & 60.2 \pm 5.1^{\#} & 65.4 \pm 5.0^{\#} \\ \text { CP } & 105.1 \pm 4.7 & 101.5 \pm 8.3^{*} & 88.0 \pm 5.5^{\# *} & 93.9 \pm 4.9^{*} & 99.5 \pm 5.9^{*} \\ \text { LID } & 99.8 \pm 7.4 & 92.5 \pm 5.9^{*} & 80.2 \pm 4.9^{*}{ }^{* *} & 85.0 \pm 4.8^{\# *} & 96.2 \pm 3.8^{*}\end{array}$

$\mathrm{dLVP} / \mathrm{dt}_{\max }$

$\begin{array}{llllll}\text { Control } & 1944 \pm 176 & 531 \pm 162^{\#} & 836 \pm 134^{\#} & 857 \pm 112^{\#} & 882 \pm 142^{\#} \\ \text { CP } & 1742 \pm 282 & 1123 \pm 211^{\# *} & 1253 \pm 220^{*} & 1239 \pm 193^{*} & 1235 \pm 185^{*} \\ \text { LID } & 1784 \pm 106 & 887 \pm 178^{\#} & 1298 \pm 171^{*} & 1401 \pm 108^{*} & 1360 \pm 153^{*}\end{array}$

$\mathrm{dLVP} / \mathrm{dt}_{\min }$

$\begin{array}{llllll}\text { Control } & -1534 \pm 143 & -330 \pm 80^{\#} & -660 \pm 124^{\#} & -666 \pm 118^{\#} & -711 \pm 131^{\#} \\ \text { CP } & -1346 \pm 173 & -766 \pm 144^{\# *} & -1036 \pm 164^{*} & -1038 \pm 142^{*} & -1054 \pm 126^{*} \\ \text { LID } & -1458 \pm 121 & -680 \pm 151^{\# *} & -1130 \pm 195^{*} & -1225 \pm 147^{*} & -1171 \pm 191^{*}\end{array}$

Table 1. Changes in $\mathrm{O}_{2}$ Delivery, $\mathrm{O}_{2}$ Consumption and cardiac contractility and relaxation at baseline, and at selected intervals during reperfusion. Values are mean \pm sem; $n=8$ hearts per group

$\mathrm{O}_{2}$ Delivery $\left(\mathrm{mmHg} \bullet \mathrm{ml} \bullet \mathrm{O}_{2} \bullet \mathrm{min}^{-1} \bullet \mathrm{g}^{-1}\right) ; \mathrm{O}_{2}$ Consumption $\left(\mathrm{O}_{2} \bullet \mathrm{g}^{-1} \bullet \mathrm{min}^{-1}\right)$; Cardiac contractility and relaxation $(\mathrm{mmHg} / \mathrm{s})$ 
NOT THE PUBLISHED VERSION; this is the author's final, peer-reviewed manuscript. The published version may be accessed by following the link in the citation at the bottom of the page.

${ }^{\#} P<0.05$ vs. baseline values;

${ }^{*} P<0.05$, each treatment vs. the control group;

${ }^{+} P<0.05$, LID vs. CP.

\section{Discussion}

Cardioplegic solutions are widely used to protect hearts against ischemic injury during revascularization or valvular procedures while on cardiopulmonary bypass. These solutions have been exhaustively modified and reformulated in attempts to reach full cardiac recovery post-operatively. $\frac{45}{}$ However, to achieve optimal protection it is important to rationally understand the mechanism by which these solutions provide protection against I/R injury. Insofar as mitochondria are implicated in I/R injury, the effects of these solutions on mitochondrial bioenergetics and function would provide a better understanding of the mechanisms of cardioprotection and the potential of a particular cardioprotective solution. Such studies could lead to a specific targeting of the mitochondrion in an attempt to improve clinical outcome.

In this study we compared the impact of two preemptive approaches to cardiac protection on mitochondrial bioenergetics and global cardiac function in an isolated heart model. These were a plasma membrane depolarizing cardioplegia with $\mathrm{KCl}$, and a normokalemic hyperpolarizing cardioplegia with lidocaine, both applied only during ischemia. To our knowledge, this is the first intact heart study to show and compare effects of these treatments on dynamic changes in mitochondrial function ( $\mathrm{NADH}, \mathrm{FAD}), \mathrm{O}_{2}{ }^{--}$generation, and $\mathrm{m}\left[\mathrm{Ca}^{2+}\right]$ during ischemia, and on the consequent changes in global and mitochondrial function during reperfusion. We found that either treatment, begun just before ischemia, resulted in a more normalized mitochondrial redox state (NADH, FAD), lower $\mathrm{O}_{2}{ }^{\bullet-}$ levels during $\mathrm{I} / \mathrm{R}$, and less $\mathrm{mCa}^{2+}$ uptake during reperfusion. This protection of mitochondria was associated with equivalent functional recovery of hearts as seen by the higher developed LVP, lower diastolic LVP, smaller infarct size, and higher coronary flow in the two treatment groups.

Mitochondrial $\left[\mathrm{Ca}^{2+}\right]$ was not significantly different between $\mathrm{CP}$ and CON throughout ischemia, even though functional recovery was

Journal of Cardiovascular Pharmacology, Vol. 54, No. 4 (October 2009): pg. 298-309. DOI. This article is (C) Lippincott Williams \& Wilkins, Inc. and permission has been granted for this version to appear in e-Publications@Marquette. Lippincott Williams \& Wilkins, Inc. does not grant permission for this article to be further copied/distributed or hosted elsewhere without the express permission from Lippincott Williams \& Wilkins, Inc. 
worst and infarct size was largest in the CON group compared to the treatment groups. It may be that a high $\mathrm{m}\left[\mathrm{Ca}^{2+}\right]$ during reperfusion rather than the $\mathrm{mCa}^{2+}$ uptake during ischemia is partially responsible for the damage induced by I/R. These data suggest that hyperpolarization with LID treatment is marginally a better approach than depolarization with high $\mathrm{K}^{+}$to specifically limit $\mathrm{mCa}^{2+}$ loading during ischemia.

\section{$C P$ and $L I D$ improve mitochondrial redox state during $I / R$}

Either NADH- or FAD-linked fluorescence can be used as a measure of mitochondrial redox state. Autofluorescence differences may reflect differences in electron flow through the electron transport chain (ETC). $\underline{27,44,46}$ Ischemia caused fluorescence to increase (more reduced state) and FAD autofluorescence to decrease (less oxidized state) in all groups, which is attributed to a slower mitochondrial respiration because of the ischemia -induced reduction in tissue $\mathrm{O}_{2}$ tension and $\mathrm{O}_{2}$ as an acceptor of electrons at complex IV. The redox state approaches the more-oxidized pre-ischemia level on reperfusion when the $\mathrm{O}_{2}$ tension rises. $\frac{47}{}$ The marked and irreversible decline in $\mathrm{NADH}$ during late ischemia and early reperfusion in the CON group compared to CP and LID could be due to an increasing volume of irreversibly oxidized mitochondria. $\underline{22}$

It is possible that a decline in NADH autofluorescence during late ischemia was due to lactic acidosis, which may alter intracellular $\mathrm{pH}$ and consequently intra mitochondrial $\mathrm{pH} . \underline{48}$ However, in preliminary isolated heart experiments, we found negligible changes in NADH between $\mathrm{pH} 6.5$ and 7.4. Moreover, the decline in NADH during early reperfusion in the CON group could be due to opening of the MPTP and depletion of mitochondrial $\mathrm{NAD}^{+49}$ and to greater cell death in this group. The decrease in redox state was associated with a larger infarct size in the CON group. This notion is supported by our previous study $\underline{22}$ showing a significant correlation between the rate of NADH decline throughout I/R and infarct size in individual hearts. Thus, the maintenance of a reduced redox state during ischemia, as shown by CP and LID, may be a prerequisite and a marker for the improved functional and metabolic recovery we observed. 


\section{$C P$ and $L I D$ reduce $\mathrm{O}_{2}{ }^{\bullet-}$ production and $\mathrm{mCa}^{2+}$ load during $I / R$}

Both excessive mitochondrial ROS and $\mathrm{Ca}^{2+}$ are implicated in I/R injury. The cause-effect relationship between excess $\mathrm{ROS}$ and $\mathrm{mCa}^{2+}$ loading during I/R injury remains unsettled. We found that both $C P$ and LID prevented the increase in $\mathrm{O}_{2}{ }^{-*}$ observed in the CON group during late ischemia. Despite their low $\mathrm{O}_{2}$ content during ischemia, mitochondria are still capable of generating ROS due to the highly reduced redox state which promotes electron donation to residual $\mathrm{O}_{2}$ to generate $\mathrm{O}_{2}{ }^{\bullet-50}$ It is noteworthy that NADH declined during late ischemia as the ROS level increased. This suggests that the increase in ROS production in the CON group led to mitochondrial damage and eventually to more cell death, and thus an irreversible decline in $\mathrm{NADH}$. The increase in ROS generation during late ischemia in the CON group could result from $\mathrm{mCa}^{2+}$ overload that leads to inhibition of respiration; $\underline{51}$ however, this does not explain why $\mathrm{O}_{2}{ }^{\bullet-}$ was lower in the $\mathrm{CP}$ group despite the higher $\mathrm{m}\left[\mathrm{Ca}^{2+}\right]$ during late ischemia.

$\mathrm{m}\left[\mathrm{Ca}^{2+}\right]$ was lower during late ischemia in the LID group than in the CON group. This may be due to inhibited cell influx and/or release of intracellular $\mathrm{Ca}^{2+}$ by LID. $\underline{52}$ Also LID may reduce the $\mathrm{Na}^{+}$loading that occurs during ischemia and consequently reduce $\mathrm{Na}^{+}$dependent $\mathrm{Ca}^{2+}$ loading. $\frac{53}{2}$ During late ischemia $\mathrm{m}\left[\mathrm{Ca}^{2+}\right]$ unexpectedly increased in the CP group to a level that was not significantly different from CON; but during reperfusion $\mathrm{m}\left[\mathrm{Ca}^{2+}\right]$ was significantly higher in the $\mathrm{CON}$ group than in the $\mathrm{CP}$ and LID treated hearts. It is unclear why $\mathrm{CP}$ treatment was associated with an increase in $\mathrm{m}\left[\mathrm{Ca}^{2+}\right]$ during ischemia. It could be due to intracellular $\mathrm{Ca}^{2+}$ loading as a consequence of $\mathrm{K}^{+-}$ induced membrane depolarization, $\underline{54}$ or result from activation of $\mathrm{Na}^{+} / \mathrm{Ca}^{2+}$ exchange, or from leakage of $\mathrm{Ca}^{2+}$ from the sarcoplasmic reticulum during arrest. $\frac{55}{2}$ Regardless of the source of increased $\mathrm{mCa}^{2+}$ during ischemia, it appears that $\mathrm{mCa}^{2+}$ loading during ischemia may not be as detrimental to cardiac recovery as $\mathrm{mCa}^{2+}$ loading during reperfusion. This observation is consistent with another study in which it was shown that the most damaging $\mathrm{Ca}^{2+}$ influx occurs during reperfusion. $\underline{56}$ 


\section{Do these cardioplegic solutions directly modulate mitochondrial function?}

The cardioprotection afforded by CP and LID may be mediated through different mechanisms that directly or indirectly impact on mitochondrial function. Although the proposed mechanism for both CP and LID for protection against I/R involves their action on the sarcolemmal membrane to arrest the heart and reduce metabolic activity, there is the possibility that they also modulate mitochondrial function directly as a mechanism for protection of the cardiac myocyte. Our study shows that perfusion of hearts with CP for only $1 \mathrm{~min}$ before ischemia caused a more reduced or (less oxidized) mitochondrial state as evidenced by the increase in NADH and a decrease in FAD. Our finding of the change in redox state during 1 min of CP perfusion is consistent with other studies that showed an increase in NADH/NAD ${ }^{+}$ and $\mathrm{FADH} / \mathrm{FAD}$ ratios in hearts perfused with hyperkalemic buffer. $\underline{57}-\underline{59}$ High $\mathrm{K}^{+} \mathrm{CP}$ could also modulate mitochondrial function by targeting mitochondrial $\mathrm{Na}^{+} / \mathrm{Ca}^{2+}$ exchange ( $\mathrm{mNCX}$ ), and thus stimulate $\mathrm{Ca}^{2+}$ efflux from mitochondria where excess $\mathrm{Ca}^{2+}$ can be stored in the sarcoplasmic reticulum during subsequent reperfusion. ${ }^{60}$ This $\mathrm{Ca}^{2+}$ dynamics may account for the fast decrease in $\mathrm{m}\left[\mathrm{Ca}^{2+}\right]$ on reperfusion to baseline levels in the CP vs. CON groups.

Unlike for high $\mathrm{K}^{+} \mathrm{CP}$, there are known direct effects of LID on mitochondria. $\underline{61}-\underline{65}$ The ability of a local anesthetic to penetrate the cellular and mitochondrial membranes depends on its lipid solubility. $\underline{66}$ LID can penetrate the cardiac cell membranes and be taken up by mitochondria. $\frac{66}{}$ Moreover, low concentrations (up to $1 \mathrm{mM}$ ) of LID have been reported to stimulate mitochondrial respiration, whereas higher concentrations to inhibit respiration. $\underline{61,65}$ The increase in mitochondrial respiration is attributed to mild uncoupling due to the electrophoretic entry of the cationic form of the amine. $\frac{67}{\text { The inhibitory }}$ effect on the other hand could be ascribed to direct inhibition of the ETC complexes by local anesthetics. $\underline{61,68}$ Therefore, it is possible that the increase in NADH we observed during the 1 min perfusion of LID could be due to a direct effect on mitochondrial electron transfer. In this way, LID could act in part like amobarbital, which blocks electron transfer at the rotenone site of complex I resulting in an increase in $\mathrm{NADH} . \underline{14}$ 
Interestingly, like amobarbital in our previous study, LID did not alter FAD, suggesting inhibition only of complex I of the ETC. This notion of specifically targeting mitochondrial complex I is supported by another study, which showed LID inhibited $\mathrm{O}_{2}$ consumption with a complex I substrate but not with a complex II substrate. $\frac{69}{}$ However unlike amobarbital, $\underline{\underline{14}}$ LID treatment attenuated basal ROS generation (Figure 3(b)). This observation agrees with another study showing that LID at comparable concentrations decreased ROS generated in neutrophils. $\frac{64}{6}$ LID has also been reported to have a direct scavenging effect on peroxynitrite $\frac{63}{3}$ and on singlet oxygen. $\underline{62}$ Therefore, the protective mechanisms of LID on mitochondrial function could be attributed to either blocking electron flow to down stream complexes (complex III), where greater ROS generation occurs during oxidative stress, 14 to scavenging of mitochondrial ROS, or to both mechanisms. Overall it is possible that LID directly modulates mitochondrial function and bioenergetics to protect mitochondria against I/R injury, but its specific effects other than those related to $\mathrm{Na}^{+}$channel function remains to be determined.

\section{Summary: high $\mathrm{K}^{+}$vs. lidocaine against IR injury}

Our study demonstrates that both high $\mathrm{K}^{+}$cardioplegia and lidocaine, when present during global cardiac ischemia but not reperfusion, help to preserve mitochondrial bioenergetics, reduce $\mathrm{mCa}^{2+}$ loading during reperfusion, and reduce ROS generation during both ischemia and reperfusion. The small but relevant changes in mitochondrial energetics during 1 min perfusion of either of these treatments before ischemia suggest that a mitochondrial related mechanism could be in part responsible for the cardioprotection conferred by these cardioplegic solutions. Although there is a definite advantage in the use of a high $\mathrm{K}^{+}$cardioplegic solution for cardioprotection, there are some disadvantages, such as $\mathrm{mCa}^{2+}$ loading as shown in the present study. Moreover, it was reported that high $\left[\mathrm{K}^{+}\right]$can decrease cardioplegic delivery in hearts with obstructed coronary arteries $\underline{9}$ due to $\mathrm{K}^{+}$-induced coronary artery smooth muscle constriction,,$\underline{9}$ whereas lidocaine may improve vasodilation and lead to a better protection against I/R injury. $\underline{70}$ Lidocaine may exhibit a better preservation of ATP compared to CP. $\stackrel{70}{ }$ In addition to the ability of lidocaine to prevent arrhythmias, maintain ion homeostasis, and 
stabilize cellular membrane potential, lidocaine may reduce the energy-dependent activity and thereby have energy-sparing effects. $\underline{70}$ Our study adds to our understanding of the mechanism of a local anesthetic vs a $\mathrm{K}^{+}$cardioplegic solution for cardiac protection by demonstrating the important role of mitochondrial function during I/R injury. Although some mitochondrial differences were noted between these treatments, we were unable to clearly ascertain if they differentially underlied the improvements in cardiac function.

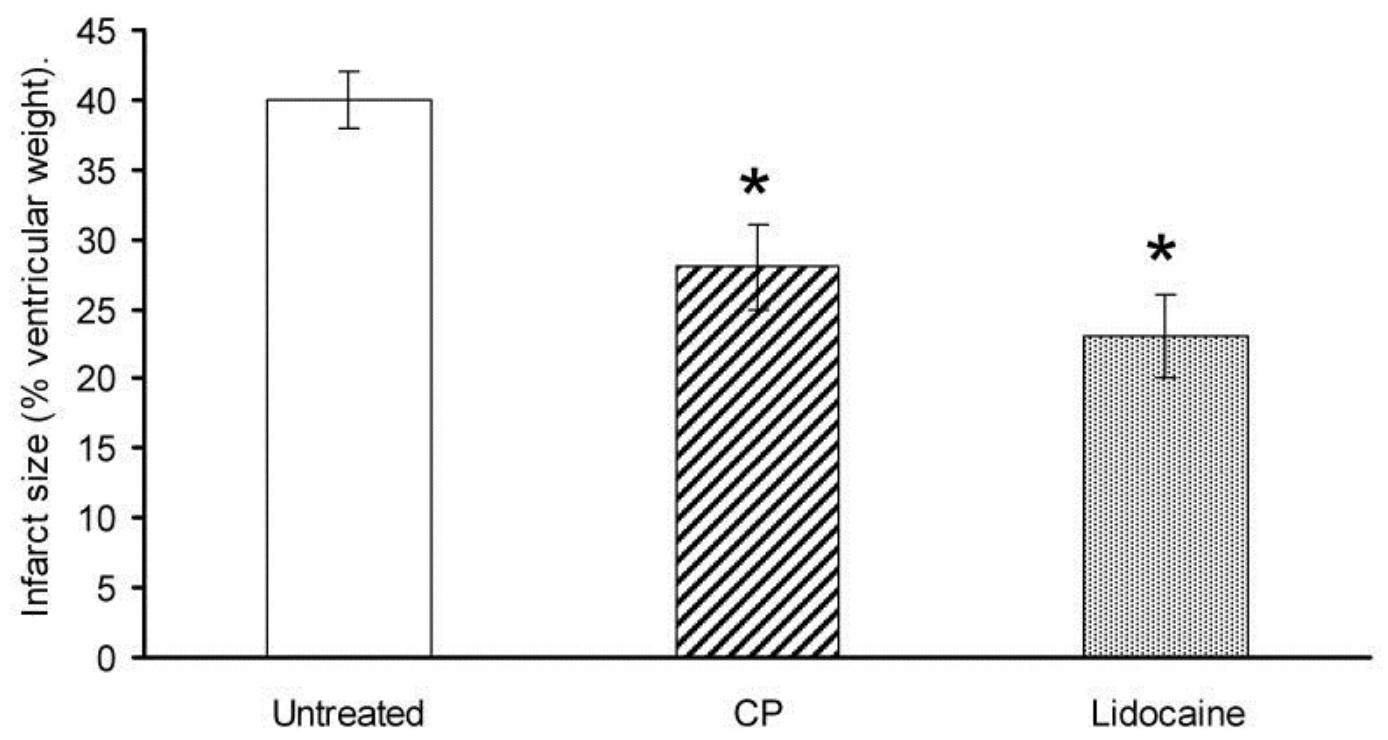

Figure 5. Infarct size as a percentage of total ventricular weight measured after 120 min reperfusion for CON $(n=15), C P(n=21)$, and LID $(n=20) * P<0.05$ CP or LID vs. CON; $+P<0.05$ LID vs. CP (ns).

\section{Acknowledgments}

The authors thank Anita Tredeau and Steven Contney for their valuable assistance.

This work was supported in part by the American Heart Association (0355608Z and 0855940G, D.F. Stowe), the National Institutes of Health (K01 HL73246, A.K.S. Camara, and R01 HL089514, D.F. Stowe), and the Veterans Administration (VA Merit 8204-05P, D.F. Stowe) 
NOT THE PUBLISHED VERSION; this is the author's final, peer-reviewed manuscript. The published version may be accessed by following the link in the citation at the bottom of the page.

\section{Footnotes}

Conflict of interest: None.

\section{References}

1. Cleveland JC, Jr, Meldrum DR, Rowland RT, Banerjee A, Harken AH. Optimal myocardial preservation: cooling, cardioplegia, and conditioning. Ann Thorac Surg. 1996;61:760-768.

2. Roe BB, Hutchinson JC, Fishman NH, Ullyot DJ, Smith DL. Myocardial protection with cold, ischemic, potassium-induced cardioplegia. J Thorac Cardiovasc Surg. 1977;73:366-374.

3. Attwell D, Cohen I, Eisner D, Ohba M, Ojeda C. The steady state TTXsensitive ("window") sodium current in cardiac Purkinje fibres. Pflugers Arch. 1979;379:137-142.

4. Jovanovic A, Alekseev AE, Lopez JR, Shen WK, Terzic A. Adenosine prevents hyperkalemia-induced calcium loading in cardiac cells: relevance for cardioplegia. Ann Thorac Surg. 1997;63:153-161.

5. Cohen NM, Wise RM, Wechsler AS, Damiano RJ., Jr Elective cardiac arrest with a hyperpolarizing adenosine triphosphate-sensitive potassium channel opener. A novel form of myocardial protection? J Thorac Cardiovasc Surg. 1993;106:317-328.

6. Chambers DJ. Mechanisms and alternative methods of achieving cardiac arrest. Ann Thorac Surg. 2003;75:S661-666.

7. Baraka A, Hirt N, Dabbous A, Taha S, Rouhana C, el-Khoury N, Ghabash M, Jamhoury $M$, Sibaii $A$. Lidocaine cardioplegia for prevention of reperfusion ventricular fibrillation. Ann Thorac Surg. 1993;55:15291533.

8. Dias RR, Stolf NA, Dalva M, Dias AR, Moreira LF, Oliveira SA. Inclusion of lidocaine in cardioplegic solutions provides additional myocardial protection. J Cardiovasc Surg (Torino) 2004;45:551-555.

9. Leicher FG, Magrassi P, LaRaia PJ, Derkac WM, Buckley MJ, Austen WG. Blood cardioplegia delivery. Deleterious effects of potassium versus lidocaine. Ann Surg. 1983;198:266-272.

10. Ross JD, Ripper R, Law WR, Massad M, Murphy P, Edelman L, Conlon B, Feinstein DL, Palmer JW, DiGregorio G, Weinberg GL. Adding bupivacaine to high-potassium cardioplegia improves function and reduces cellular damage of rat isolated hearts after prolonged, cold storage. Anesthesiology. 2006;105:746-752.

11. Becker LB. New concepts in reactive oxygen species and cardiovascular reperfusion physiology. Cardiovasc Res. 2004;61:461-470. 
NOT THE PUBLISHED VERSION; this is the author's final, peer-reviewed manuscript. The published version may be

accessed by following the link in the citation at the bottom of the page.

12. Downey JM. Free radicals and their involvement during long-term myocardial ischemia and reperfusion. Annu Rev Physiol. 1990;52:487504.

13. Li C, Jackson RM. Reactive species mechanisms of cellular hypoxiareoxygenation injury. Am J Physiol Cell Physiol. 2002;282:C227-241.

14. Aldakkak M, Stowe DF, Chen Q, Lesnefsky EJ, Camara AK. Inhibited mitochondrial respiration by amobarbital during cardiac ischaemia improves redox state and reduces matrix $\mathrm{Ca}^{2+}$ overload and ROS release. Cardiovasc Res. 2008;77:406-415.

15. Chen Q, Hoppel CL, Lesnefsky EJ. Blockade of electron transport before cardiac ischemia with the reversible inhibitor amobarbital protects rat heart mitochondria. J Pharmacol Exp Ther. 2006;316:200-207.

16. Lesnefsky EJ, Chen Q, Moghaddas S, Hassan MO, Tandler B, Hoppel CL. Blockade of electron transport during ischemia protects cardiac mitochondria. J Biol Chem. 2004;279:47961-47967.

17. Nadtochiy SM, Burwell LS, Brookes PS. Cardioprotection and mitochondrial S-nitrosation: effects of S-nitroso-2-mercaptopropionyl glycine (SNO-MPG) in cardiac ischemia-reperfusion injury. J Mol Cell Cardiol. 2007;42:812-825.

18. An J, Varadarajan SG, Camara A, Chen Q, Novalija E, Gross GJ, Stowe DF. Blocking $\mathrm{Na}^{+} / \mathrm{H}^{+}$exchange reduces $\left[\mathrm{Na}^{+}\right]_{i}$ and $\left[\mathrm{Ca}^{2+}\right]_{i}$ load after ischemia and improves function in intact hearts. Am J Physiol Heart Circ Physiol. 2001;281:H2398-2409.

19. Camara AK, Riess ML, Kevin LG, Novalija E, Stowe DF. Hypothermia augments reactive oxygen species detected in the guinea pig isolated perfused heart. Am J Physiol Heart Circ Physiol. 2004;286:H12891299.

20. Kevin LG, Camara AK, Riess ML, Novalija E, Stowe DF. Ischemic preconditioning alters real-time measure of $\mathrm{O}_{2}$ radicals in intact hearts with ischemia and reperfusion. Am J Physiol Heart Circ Physiol. 2003;284:H566-574.

21. Kevin LG, Novalija E, Riess ML, Camara AK, Rhodes SS, Stowe DF. Sevoflurane exposure generates superoxide but leads to decreased superoxide during ischemia and reperfusion in isolated hearts. Anesth Analg. 2003;96:949-955.

22. Riess ML, Camara AK, Chen Q, Novalija E, Rhodes SS, Stowe DF. Altered $\mathrm{NADH}$ and improved function by anesthetic and ischemic preconditioning in guinea pig intact hearts. Am J Physiol Heart Circ Physiol. 2002;283:H53-60.

23. Riess ML, Camara AK, Novalija E, Chen Q, Rhodes SS, Stowe DF. Anesthetic preconditioning attenuates mitochondrial $\mathrm{Ca}^{2+}$ overload during ischemia in guinea pig intact hearts: reversal by 5 hydroxydecanoic acid. Anesth Analg. 2002;95:1540-1546. 
24. Bunger R. The stabilizing effect of pyruvate on the function and metabolism of isolated perfused guinea pig hearts. Fortschr Med. 1978;96:1246.

25. Bunger R, Haddy FJ, Querengasser A, Gerlach E. An isolated guinea pig heart preparation with in vivo like features. Pflugers Arch. 1975;353:317-326.

26. Scaduto RC, Jr, Grotyohann LW. Hydrolysis of $\mathrm{Ca}^{2+}$-sensitive fluorescent probes by perfused rat heart. Am J Physiol Heart Circ Physiol. 2003;285: H2118-2124.

27. Camara AK, Aldakkak M, Heisner JS, Rhodes SS, Riess ML, An J, Heinen A, Stowe DF. ROS scavenging before $27^{\circ} \mathrm{C}$ ischemia protects hearts and reduces mitochondrial $\mathrm{ROS}, \mathrm{Ca}^{2+}$ overload, and changes in redox state. Am J Physiol Cell Physiol. 2007;292:C2021-2031.

28. Brandes $R$, Bers DM. Increased work in cardiac trabeculae causes decreased mitochondrial NADH fluorescence followed by slow recovery. Biophys J. 1996;71:1024-1035.

29. Chance B, Williamson JR, Jamieson D, Schoenner B. Properties and kinetics of reduced pyridine nucleotide fluorescence of the isolated and in vivo rat heart. Biochem Z. 1965;341:357-377.

30. Nuutinen EM. Subcellular origin of the surface fluorescence of reduced nicotinamide nucleotides in the isolated perfused rat heart. Basic Res Cardiol. 1984;79:49-58.

31. Oldendorf WH, Cornford ME, Brown WJ. The large apparent work capability of the blood-brain barrier: a study of the mitochondrial content of capillary endothelial cells in brain and other tissues of the rat. Ann Neurol. 1977;1:409-417.

32. Barth E, Stammler G, Speiser B, Schaper J. Ultrastructural quantitation of mitochondria and myofilaments in cardiac muscle from 10 different animal species including man. J Mol Cell Cardiol. 1992;24:669-681.

33. Vinnakota KC, Bassingthwaighte JB. Myocardial density and composition: a basis for calculating intracellular metabolite concentrations. Am J Physiol Heart Circ Physiol. 2004;286:H1742-1749.

34. Miyata H, Silverman HS, Sollott SJ, Lakatta EG, Stern MD, Hansford RG. Measurement of mitochondrial free $\mathrm{Ca}^{2+}$ concentration in living single rat cardiac myocytes. Am J Physiol. 1991;261:H1123-1134.

35. Rhodes SS, Ropella KM, Camara AK, Chen Q, Riess ML, Stowe DF. How inotropic drugs alter dynamic and static indices of cyclic myoplasmic $\left[\mathrm{Ca}^{2+}\right]$ to contractility relationships in intact hearts. $]$ Cardiovasc Pharmacol. 2003;42:539-553.

36. Camara AK, Chen Q, An J, Novalija E, Riess ML, Rhodes SS, Stowe DF. Comparison of hyperkalemic cardioplegia with altered $\left[\mathrm{CaCl}_{2}\right]$ and $\left[\mathrm{MgCl}_{2}\right]$ on $\left[\mathrm{Ca}^{2+}\right]_{i}$ transients and function after warm global ischemia in isolated hearts. J Cardiovasc Surg (Torino) 2004;45:1-13. 
NOT THE PUBLISHED VERSION; this is the author's final, peer-reviewed manuscript. The published version may be

accessed by following the link in the citation at the bottom of the page.

37. Vanden Hoek TL, Li C, Shao Z, Schumacker PT, Becker LB. Significant levels of oxidants are generated by isolated cardiomyocytes during ischemia prior to reperfusion. J Mol Cell Cardiol. 1997;29:2571-2583.

38. Zhao H, Joseph J, Fales HM, Sokoloski EA, Levine RL, Vasquez-Vivar J, Kalyanaraman $\mathrm{B}$. Detection and characterization of the product of hydroethidine and intracellular superoxide by HPLC and limitations of fluorescence. Proc Natl Acad Sci U S A. 2005;102:5727-5732.

39. Zhao H, Kalivendi S, Zhang H, Joseph J, Nithipatikom K, Vasquez-Vivar J, Kalyanaraman B. Superoxide reacts with hydroethidine but forms a fluorescent product that is distinctly different from ethidium: potential implications in intracellular fluorescence detection of superoxide. Free Radic Biol Med. 2003;34:1359-1368.

40. Riess ML, Camara AK, Kevin LG, An J, Stowe DF. Reduced reactive $\mathrm{O}_{2}$ species formation and preserved mitochondrial NADH and $\left[\mathrm{Ca}^{2+}\right]$ levels during short-term $17^{\mathrm{a}} \mathrm{C}$ ischemia in intact hearts. Cardiovasc Res. 2004;61:580-590.

41. Brandes R, Figueredo VM, Camacho SA, Baker AJ, Weiner MW. Investigation of factors affecting fluorometric quantitation of cytosolic $\left[\mathrm{Ca}^{2+}\right]$ in perfused hearts. Biophys J. 1993;65:1983-1993.

42. Stowe DF, Fujita S, An J, Paulsen RA, Varadarajan SG, Smart SC. Modulation of myocardial function and $\left[\mathrm{Ca}^{2+}\right]$ sensitivity by moderate hypothermia in guinea pig isolated hearts. Am J Physiol. 1999;277: H2321-2332.

43. Aldakkak M, Stowe DF, Heisner JS, Spence M, Camara AK. Enhanced $\mathrm{Na}^{+} / \mathrm{H}^{+}$exchange during ischemia and reperfusion impairs mitochondrial bioenergetics and myocardial function. J Cardiovasc Pharmacol. 2008;52:236-244.

44. An J, Camara AK, Rhodes SS, Riess ML, Stowe DF. Warm ischemic preconditioning improves mitochondrial redox balance during and after mild hypothermic ischemia in guinea pig isolated hearts. Am J Physiol Heart Circ Physiol. 2005;288:H2620-2627.

45. Stowe DF, Camara AK, Heisner JS, Aldakkak M, Harder DR. Ten-hour preservation of guinea pig isolated hearts perfused at low flow with air-saturated Lifor solution at 26 \{degrees\}C: comparison to ViaSpan solution. Am J Physiol Heart Circ Physiol. 2007;293:H895-901.

46. An J, Camara AK, Riess ML, Rhodes SS, Varadarajan SG, Stowe DF. Improved mitochondrial bioenergetics by anesthetic preconditioning during and after 2 hours of 27 degrees $C$ ischemia in isolated hearts. J Cardiovasc Pharmacol. 2005;46:280-287.

47. Cairns CB, Ferroggiaro AA, Walther JM, Harken AH, Banerjee A. Postischemic administration of succinate reverses the impairment of oxidative phosphorylation after cardiac ischemia and reperfusion injury. Circulation. 1997;96:II-260-265.

Journal of Cardiovascular Pharmacology, Vol. 54, No. 4 (October 2009): pg. 298-309. DOI. This article is (C) Lippincott Williams \& Wilkins, Inc. and permission has been granted for this version to appear in e-Publications@Marquette. Lippincott Williams \& Wilkins, Inc. does not grant permission for this article to be further copied/distributed or hosted elsewhere without the express permission from Lippincott Williams \& Wilkins, Inc. 
NOT THE PUBLISHED VERSION; this is the author's final, peer-reviewed manuscript. The published version may be accessed by following the link in the citation at the bottom of the page.

48. Griffiths EJ, Lin H, Suleiman MS. NADH fluorescence in isolated guinea-pig and rat cardiomyocytes exposed to low or high stimulation rates and effect of metabolic inhibition with cyanide. Biochem Pharmacol. $1998 ; 56: 173-179$.

49. Di Lisa F, Menabo R, Canton M, Barile M, Bernardi P. Opening of the mitochondrial permeability transition pore causes depletion of mitochondrial and cytosolic NAD ${ }^{+}$and is a causative event in the death of myocytes in postischemic reperfusion of the heart. J Biol Chem. 2001;276:2571-2575.

50. Hess ML, Manson NH. Molecular oxygen: friend and foe. The role of the oxygen free radical system in the calcium paradox, the oxygen paradox and ischemia/reperfusion injury. J Mol Cell Cardiol. 1984;16:969-985.

51. Kushnareva Y, Murphy AN, Andreyev A. Complex I-mediated reactive oxygen species generation: modulation by cytochrome $c$ and $N A D(P)^{+}$ oxidation-reduction state. Biochem J. 2002;368:545-553.

52. Almers W, Best PM. Effects of tetracaine on displacement currents and contraction of frog skeletal muscle. J Physiol. 1976;262:583-611.

53. Haigney MC, Lakatta EG, Stern MD, Silverman HS. Sodium channel blockade reduces hypoxic sodium loading and sodium-dependent calcium loading. Circulation. 1994;90:391-399.

54. Lopez JR, Jahangir R, Jahangir A, Shen WK, Terzic A. Potassium channel openers prevent potassium-induced calcium loading of cardiac cells: possible implications in cardioplegia. J Thorac Cardiovasc Surg. 1996;112:820-831.

55. Watanabe M, Egi K, Shimizu M, Nakahara H, Tanaka H, Sakamoto T, Sunamori M. Non-depolarizing cardioplegia activates $\mathrm{Ca}^{2+}$-ATPase in sarcoplasmic reticulum after reperfusion. Eur ] Cardiothorac Surg. 2002;22:951-956.

56. Allen DG, Xiao XH. Role of the cardiac $\mathrm{Na}^{+} / \mathrm{H}^{+}$exchanger during ischemia and reperfusion. Cardiovasc Res. 2003;57:934-941.

57. Hassinen IE, Hiltunen K. Respiratory control in isolated perfused rat heart. Role of the equilibrium relations between the mitochondrial electron carriers and the adenylate system. Biochim Biophys Acta. 1975;408:319-330.

58. Hiltunen JK, Hassinen IE. Energy-linked regulation of glucose and pyruvate oxidation in isolated perfused rat heart. Role of pyruvate dehydrogenase. Biochim Biophys Acta. 1976;440:377-390.

59. Katz A, Edlund A, Sahlin K. NADH content and lactate production in the perfused rabbit heart. Acta Physiol Scand. 1987;130:193-200.

60. Consolini AE, Ragone MI, Conforti P, Volonte MG. Mitochondrial role in ischemia-reperfusion of rat hearts exposed to high- $\mathrm{K}^{+}$cardioplegia and 
NOT THE PUBLISHED VERSION; this is the author's final, peer-reviewed manuscript. The published version may be accessed by following the link in the citation at the bottom of the page.

clonazepam: energetic and contractile consequences. Can J Physiol Pharmacol. 2007;85:483-496.

61. Chazotte B, Vanderkooi G. Multiple sites of inhibition of mitochondrial electron transport by local anesthetics. Biochim Biophys Acta. 1981;636:153-161.

62. Das KC, Misra HP. Lidocaine: a hydroxyl radical scavenger and singlet oxygen quencher. Mol Cell Biochem. 1992;115:179-185.

63. Gunaydin B, Demiryurek AT. Interaction of lidocaine with reactive oxygen and nitrogen species. Eur J Anaesthesiol. 2001;18:816-822.

64. Mikawa K, Akamatsu H, Nishina K, Shiga M, Maekawa N, Obara H, Niwa Y. Inhibitory effect of local anaesthetics on reactive oxygen species production by human neutrophils. Acta Anaesthesiol Scand. 1997;41:524-528.

65. Tarba C, Cracium C. A comparative study of the effects of procaine, lidocaine, tetracaine and dibucaine on the functions and ultrastructure of isolated rat liver mitochondria. Biochim Biophys Acta. 1990;1019:19-28.

66. Grouselle M, Tueux O, Dabadie P, Georgescaud D, Mazat JP. Effect of local anaesthetics on mitochondrial membrane potential in living cells. Biochem J. 1990;271:269-272.

67. Dabadie $P$, Bendriss $P$, Erny $P$, Mazat JP. Uncoupling effects of local anesthetics on rat liver mitochondria. FEBS Lett. 1987;226:77-82.

68. Sztark F, Malgat M, Dabadie P, Mazat JP. Comparison of the effects of bupivacaine and ropivacaine on heart cell mitochondrial bioenergetics. Anesthesiology. 1998;88:1340-1349.

69. Haschke RH, Fink BR. Lidocaine effects on brain mitochondrial metabolism in vitro. Anesthesiology. 1975;42:737-740.

70. Dobson GP, Jones MW. Adenosine and lidocaine: a new concept in nondepolarizing surgical myocardial arrest, protection, and preservation. J Thorac Cardiovasc Surg. 2004;127:794-805. 